值と比較したところ約 2 倍の值を示した。よって本実験 では1/2倍にした值を使用した。抜け時間，硫化ソーダ法 により，約 $15 \mathrm{~g} / \ell$ を超えなければ，90秒自現機において 定着主薬の消費などの心配はないと思われる。銀濃度の 測定範囲が， $0 \sim 30 \mathrm{~g} / \ell, \mathrm{pH} 4$ 〜 6゙らいを細かく測定 できれば，定着液の管理面でより有用と思われる。

322. 定着液の疲労度が写真濃度に及ぼす影響について (第一報)

福島県立医科大学附属病院放射線科

○青山正勝・遊佐 烈・半田信人

樋口義典・佐藤孝則・片倉俊彦

伊藤正已 ・上田 稔

自現機において定着液槽内に持込む現像液が定着を疲 労させる.CRT フィルムと直接フィルムのコントロール ピース, 腹部 CT 写真を同時現像し疲労度が写真濃度に 及ぼす影響と, 容認度について検討をした。定着新液に 現像液を $0 \%$ から $30 \%$ 迄混入し, コントロールピースの 濃度特性曲線を求めた。また, 腹部 CT 写真の肝, 腎の 正常部とチスト部をマイクロデンシトメータで計測し, 混入率による変化をみた。その結果として定着液の疲労 度が写真濃度に関与している.CRTフィルムにおいて肩 部より $\mathrm{D}_{\mathrm{MAx}}$ にかけての変化が写真全体をフラットにし， シャウカステンの輝度により病巣等の判別が困難となる。 混入率の割合が10\%以内であれば，写真濃度に影響がで にくいことが判った。

323. 現像液の色調変化と活性度について（マンセル表色 系による液管理）第 1 報

神戸大学医学部附属病院中央放射線部

○古東正宜・小寺滋子 ・ 岡山貴宣

今井方丈・松永 登・北山卓弘

小西六写真工業(侏)

岡田敏正

〔目的〕現像液の活性度を定量的に把握する目的で, マンセル表色系を利用し, 現像液の色調変化とその活性 度について検討した。

〔方法〕(1)現像液の空気酸化による着色変化と, マン セル表色系を対比させた。（スターラ使用)(2)現像液の着 色変化と写真特性との相関を求めた. (センシトメー夕使 用，手現像）(3)自現機通常使用でのランニングによる現 像液の着色変化と写真特性の対比を行った。

〔結果〕（1)マンセル表色系を用いることにより，着色 の数値化表示が可能となった。(2)現像液の着色は, 空気 酸化の影響が大きい. (3)現像液の活性度に関し，色調変 化をマンセル表示することにより，色調変化による自現
機の品質管理が可能となるであろう。

\section{4. 簡単な定着液中の銀定量法}

近畿大学ライフサイエンス研究所

○山本義憲

近畿大学医学部

浅香征洋

近畿大学医学部附属病院中央放射線部

美甘美嘉子

西宮市立中央病院中央放射線部

田辺康治・諏訪田智敬・森本治男

安田火災海上保険KK大阪診療所

津山泰子

定着液と $\mathrm{H}_{2} \mathrm{O}_{2}$ を反応させると, $\mathrm{Ag}_{2} \mathrm{~S}$ と $\mathrm{AgBr}$ が生 成し沈澱する。(急激な反応で注意を要する)この反応 は, 競合反応で化合物に含まれる, $\mathrm{Ag}_{2} \mathrm{~S}$ と $\mathrm{AgBr}$ の比率 は, 周囲温度, 添加速度によって変化する. 反応時の条 件, 温度 $25^{\circ} \mathrm{C} \sim 27^{\circ} \mathrm{C}$, 定着液と同量の $\mathrm{H}_{2} \mathrm{O}_{2}(30 \%)$ 急速 添加で $\mathrm{Ag}_{2} \mathrm{~S} \mathrm{10 \% ,AgBr} 90 \%$ と一定の值を示す.したが って，生成した化合物の $60 \%$ 銀量とすれば，フォルハ ルト法との詥差，5\%以内の精度で測定可能である．簡 便には，半定量試験紙と化合物の力サ（高，低）により， 相対的な目安值を知ることができる。フィルムは，省銀 化設計がなされており，銀量を測定して適正な管理を行 い，補充量など，省資源化を計るべきと考える.

325. X 線撮影系における乾式現像（dry silver）の適用 について（第 1 報 その原理と基礎実験）

国立循環器病センター放射線診療部

○片㴊哲朗・若松孝司

内田英治・東儀英明

現在 X 線フィルムのほとんどは湿式現像によって行 われているが，われわれは新しい感光材料の現像法とし て熱による乾式現像を試みた。これは $3 \mathrm{M}$ 社が開発した dry silver と呼ばれるもので，今回はこの熱現像の原理 とその一部を X 線撮影系に応用した.その結果, I.I. 撮影 系においては感度等の問題があるが，絞りや撮影条件に よっては撮影可能であった。また CT, DSA などの CRT フィルムには早期害用可能であると思われる。しかしこ れらを一般スクリーン系に適用するのは現段階において 難しい.このシステムは多くの改良の余地は残っている が，将来的には実現性が高い。これら乾式現像が臨床的 に使用されるようになれば，X 線撮影系は新たな変革期 をむかえるものであろうと考えている。

\section{座長集約}

このセクションは現像管理に関する演題群で，3 題は 
定着液の管理，1題は現像液の管理と新しいプロセスを 持った乾式現像機（ドライシルバー）についての発表で ある。定着液の管理は現像液と同様に重要なプロセスの 一つである。これに関する報告があったことを喜ばしく 思っている. 定着は光の当らない八ロゲン化銀を溶解し 去って，その後に光が当っても，もはや変化するものが ないようにする現像である。

演題321は銀濃度を 6 段階で表示し, 原子吸光器の定量 值とシルバー，チェック值の比較からシルバー，チェッ クの精度を求め，その数值に基づいて定着液中の $\mathrm{Ag}$ 量 と定着液の疲労の関係をみたものである。結果はベース 濃度より0.3上昇した時, 定着液は疲労していると判断 し，その時の銀濃度が $15 \mathrm{~g} / \ell$ を越えなければ銀濃度につ いては心配ないとされているが，その時画質に対する影 響についての物理評価が加えてあればよかったと思われ る.

参考：現在の四切 1 枚の総重量は約 $20.7 \mathrm{~g}$ （レギュラ 一) 中，銀量は約 $4.2 \mathrm{~g}$ 位である.

演題322は定着液中に現像液の混入が写真濃度に及ぼ す影響についてみたものである。定着液の新液に現像液 を 5 〜 $30 \%$ まで混入させ，その時の写真濃度を特性曲線 から求め，評価を定着の面から判定した点にある。結果 は特性曲線の肩から $\mathrm{D}_{\max }$ に変化があり, 定着液の疲労 は写真濃度に及ぼす要因としている.321席とも関連する が，現像液槽から強い塩基性の現像液が定着液槽内に混 入すれば，定着液は污染され，定着液は劣化する。そし て定着の速効性が失われるために現像の進行を助長させ る、したがって特性曲線の足部が上り，画像はカブッ夕 ような写真になる。そして粒状性も悪くなる。

演題323は現像液の管理を定量的に把握するためにマ ンセル表示系の応用についてみたものである。現像液の 活性度を色の三要素, 色相 $(\mathrm{H})$, 明度 $(\mathrm{V})$, 彩度 $(\mathrm{C})$ に基づいて示す方法 $\mathrm{HV} / \mathrm{C}$ の形式加ら写真特性を求め, 液の着色度は数値表示でその劣化を認知し, 定量的に把 握しようとした。約10年位前に A 社の現像液を使用して いた時, 約 6 ケ月使用しても透明度は新液と殆んど変わ らないが，現像能力に低下が認められ，その判定は特性 曲線から求めたことを追記する。

演題324は定着液中の銀定量から液の状態と能力の限 界の判定についてである. $\mathrm{H}_{2} \mathrm{O}_{2}$ を用いて $\mathrm{Ag}$ 化合物を生 成させ, 硫酸で処理した $\mathrm{Ag}_{2} \mathrm{~S}$ 量をVolhard 法で求め, 硫化銀と臭化銀の比率をフィルム中の総銀量の相関で求 めている。X線写真の画質扔よび品質管理は現像液だけ でなく，定着液の管理やラックの材質，状態によって大
きく変化する.その便法として $\mathrm{H}_{2} \mathrm{O}_{2}$ 法を取り上げ, 化学 的に管理する方法の提唱は結構な事と思われ，今後一層 の研究を希望する。

演題325は $3 \mathrm{M}$ 社が開発した乾式現像という新しい現 像処理方法の原理之臨床への応用についてである.4 種 の結合剤から成る感熱性銀化合物中のハロゲン化銀は光 分解で潜像を形成し，熱現像工程で画像を得る，従来の 湿式とは異なり，数秒間で現像が出来，小型で安全性に 秀れているが，画質拀よび感度等の点に今後の研究課題 が有るとしている。一層の研究を期待する。

質問 322 席 (柴田，新小倉病院） 1. 演題の疲労とい う用語は適切ではないのではないか，2．定着液槽内へ の現像液混入量が多く, 普通0.1\%位ではないか.

答 疲労についてはこれでよいと思う。あくまでも実 験を目的とした数值なので，問題ないと思う。

質問 323 席 (藤本, 豊中保健所) 現像液はメ一力によ って着色度は異なり，現像液，作成するたびに液の色が 変る，この場合マンセル表示も変ると思われるが，この 点についてどのように考えているか.

答 今後の研究として進めて行きたい.

質問 322席 (田中,鶴見大学) 定着液の中に現像液が 混入した場合，なぜ？ 高濃度部が低下するのか，その 原因を教えていただきたい。

答 ハイドロキノンのいたずらによる硬膜化から来て いるのではないかと思われる。（青山）一つの意兒として 補充液のバランスから来ているのではないか.（近大，山 本)

$\mathrm{X}$ 線フィルム-1

座長 遠山坦彦 (高知医科大学)

\section{6. 胸部撮影専用新オルソタイプフィルムコダック TMC について}

長瀬産業株式会社コダック製品事業部 田中秀幸

昨春発表のコニークかつ実用的胸部撮影専用フィルム $\mathrm{OC}$ に続きコダック社は新たに $\mathrm{T}$ 粒子乳剤製造技術を活 用した新タイプ胸部専用オルソタイプフィルム $\mathrm{TMC}$ 開発したのでその特性を紹介させて頂く，TMCフィル ムは低濃度部では感度，コントラスト共に OC, OL フィ ルムのほぼ中間の特性を有するが中高濃度部では逆に両 フィルムよりもコントラストが向上，胸部写真では縌隔 部の情報をそこなわずに胸野部での視覚的鮮鋭度を高め る効果を得ている。しかも丁粒子乳刜製造技術の活用に より全体に一層シャープな画像の入手が可能となった。 